\title{
Morphologic evolution of the Central Andes of Peru
}

\author{
Laura Gonzalez $\cdot$ O. Adrian Pfiffner
}

Received: 15 July 2010/Accepted: 25 April 2011/Published online: 5 June 2011

(C) Springer-Verlag 2011

\begin{abstract}
In this paper, we analyze the morphology of the Andes of Peru and its evolution based on the geometry of river channels, their bedrock profiles, stream gradient indices and the relation between thrust faults and morphology. The rivers of the Pacific Basin incised Mesozoic sediments of the Marañon thrust belt, Cenozoic volcanics and the granitic rocks of the Coastal Batholith. They are mainly bedrock channels with convex upward shapes and show signs of active ongoing incision. The changes in lithology do not correlate with breaks in slope of the channels (or knick points) such that the high gradient indices (K) with values between 2,000-3,000 and higher than 3,000 suggest that incision is controlled by tectonic activity. Our analysis reveals that many of the ranges of the Western Cordillera were uplifted to the actual elevations where peaks reach to $6,000 \mathrm{~m}$ above sea level by thrusting along steeply dipping faults. We correlate this uplift with the Quechua Phase of Neogene age documented for the Subandean thrust belt. The rivers of the Amazonas Basin have steep slopes and high gradient indices of 2,000-3,000 and locally more than 3,000 in those segments where the rivers flow over the crystalline basement of the Eastern Cordillera affected by vertical faulting. Gradient indices decrease to 1,000-2,000 within the east-vergent thrust belt of the Subandean Zone. Here a correlation between breaks in river channel slopes and location of thrust faults can be established, suggesting that the young, Quechua Phase
\end{abstract}

\footnotetext{
L. Gonzalez $(\bowtie) \cdot$ O. A. Pfiffner

Institute of Geological Sciences, University of Bern,

Baltzerstrasse 1+3, 3012 Bern, Switzerland

e-mail: gonzalez@geo.unibe.ch

O. A. Pfiffner

e-mail: pfiffner@geo.unibe.ch
}

thrust faults of the Subandean thrust belt, which involve Neogene sediments, influenced the channel geometry. In the eastern lowlands, these rivers become meandering and flow parallel to anticlines that formed in the hanging wall of Quechua Phase thrust faults, suggesting that the river courses were actively displaced outward into the foreland.

Keywords Peruvian Andes · Morphology ·

River profiles · Stream gradient indices - Uplift

\section{Introduction}

The Central Andes of Peru correspond to a continental active margin related to the subduction system between the oceanic plates of Nazca beneath the continental plate of South America (Fig. 1). In this segment, the Nazca Plate descends at approximately $30^{\circ}$, beneath the South American plate near to the trench and then it changes slope to become subhorizontal at a depth of $100 \mathrm{~km}$ (Barazangi and Isacks 1976; Lindo et al. 1992). The Peruvian Andes are made up of three geomorphologic units. The Western Cordillera consists of Jurassic sandstones and carbonates and Early Cretaceous volcaniclastics (Morro Solar, Imperial, and Casma groups) in the coastal region that were intruded by the Coastal Batholith in the Early Cretaceous (Cobbing 1985; Atherton and Webb 1989). To the east, the Marañon thrust belt displays folding and east verging thrust faulting of Mesozoic strata. Cenozoic magmatism produced granitic intrusions into this thrust belt, and Eocene and Miocene volcanics (Calipuy group and equivalents) were deposited unconformably on top of the deformed and eroded Marañon thrust belt (Jaillard et al. 2000). Much of the Western Cordillera exceeds 5,000 $\mathrm{m}$ in elevation, and several peaks rise to more than $6,000 \mathrm{~m}$. 
Fig. 1 Topographic map showing the large-scale geomorphic features of the Peruvian Andes and the PeruChile Trench. The Andes appear as a broad band with elevations above $4,000 \mathrm{~m}$ with an escarpment to the SW toward the Pacific and to the NE toward the lowland of Amazonia. The Western and Eastern Cordilleras contain a series of peaks rising to higher levels and straddling these escarpments

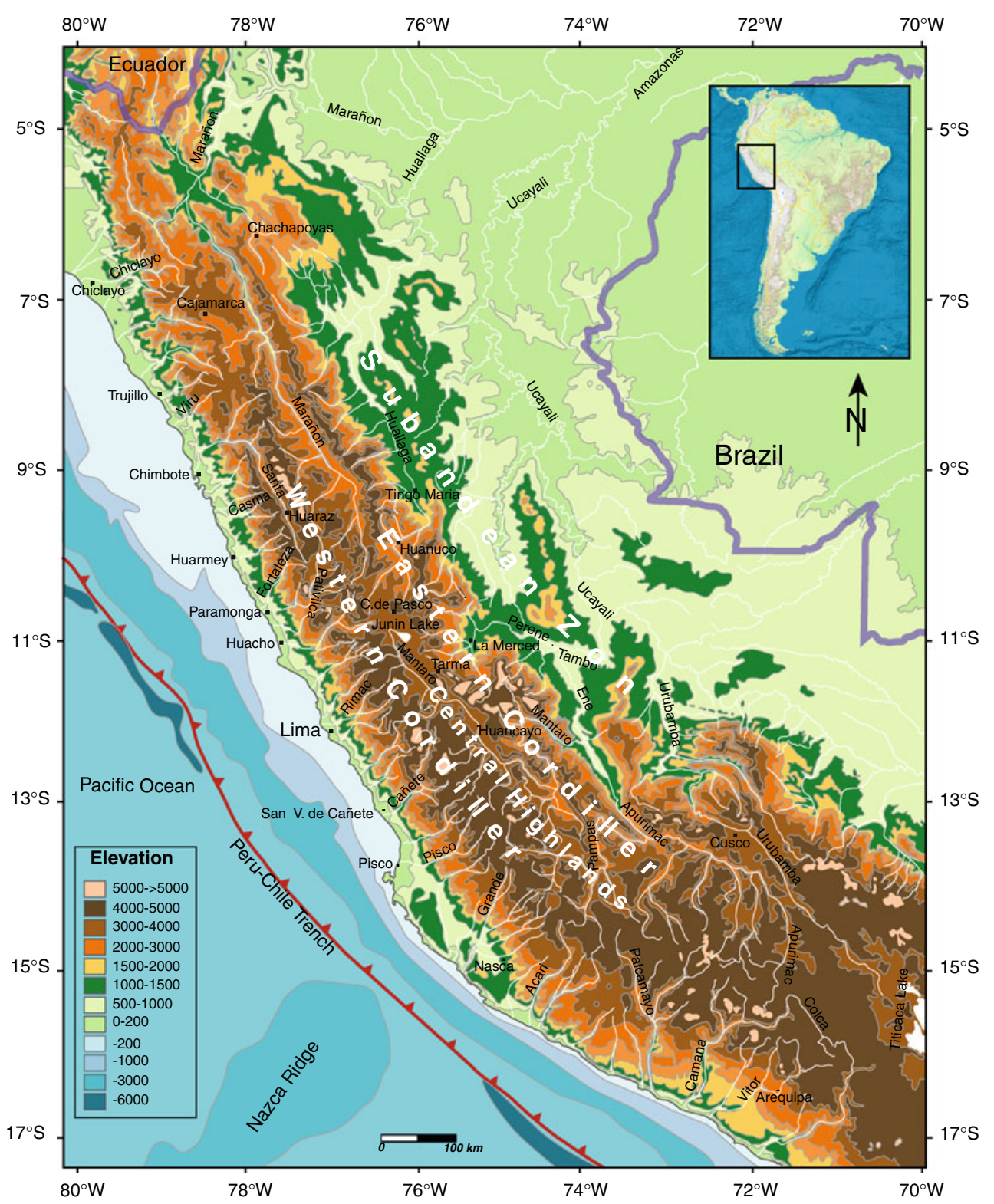

crystalline basement, Paleozoic, Mesozoic, and Cenozoic strata. It is characterized by low elevation and forms the transition to the foreland of the Brazilian shield.

The evolution of the Peruvian Andes has been dominated by compressional deformation events that in general propagated from west to east. Early Cretaceous plutons of the Coastal Batholith intruded already folded Jurassic to Early Cretaceous strata, and it suggests an Early Cretaceous phase of shortening in the Pacific coastal area of the Western Cordillera. This deformation is referred to as Mochica Phase (Steinman 1929; Mégard 1984; Soler and Bonhomme 1990; Jaillard and Soler 1996; Jaillard et al. 2000). In the Marañon thrust belt of the Western Cordillera, a change from marine sandstones and limestones to continental, fine-grained and mainly argillaceous sediments 
occurred in early Late Cretaceous times (Mégard 1978, 1984; Jaillard 1994, 1996). This change suggesting uplift has been designated as Peruvian Phase, and Mégard (1978, 1984) even suspected that this uplift was caused by a phase of compression. The Incaic Phase of mid to late Eocene age is commonly considered as the main Andean phase of shortening in the Peruvian Andes and is related to the development of the tight upright folds of the Marañon foldand-thrust belt in the Western Cordillera (Mégard 1984). The overlying volcanics are slightly younger (middle Eocene) and unconformably overly these tight folds, producing a major unconformity. The volcanics in turn are affected by a still younger deformation phase, the Quechua Phase, producing gentle open folds within these deposits (Mégard 1984; Jaillard and Soler 1996; Jaillard et al. 2000). The Quechua Phase in fact is a series of local deformation episodes that left their traces in all parts of the entire orogen. In the east, the formation of the Subandean thrust belt is attributed to the Quechua Phase (Mégard 1984). In the Western Cordillera, Quechua Phase thrusting put Cretaceous strata onto Eocene-Oligocene volcanics and vertical motions between the Cordillera Blanca and the Cordillera Negra juxtaposed a Late Miocene-Pliocene batholith next to Late Miocene volcanics. In the latter case, faulting even affected Holocene gravels shed from the Cordillera Blanca. In the Central Highlands, Pleistocene gravels were tilted and locally even folded by the Quechua Phase deformation. Thus, the various episodes within the Quechua Phase do not seem to show a spatial progradation with time, rather it seems that the entire orogen was deformed in a spotty pattern over the last 20 million years.

The aim of this paper is to analyze the geomorphic features like drainage networks, local relief and elevation and stream gradients of rivers in order to understand how these features are reflecting bedrock lithology and structures related to mountain building processes.

The morphology of a mountain range is controlled by tectonic uplift at large scale, which affects the entire orogen, and at smaller scale by faulting. This uplift is counterbalanced by erosion that shapes the surface at even smaller scale. Although glacial erosion and mass movements are important, the primary features shaping the larger-scale morphology are river valleys. A useful tool to describe the state of a river valley is to determine the river channel gradient. A river channel is considered to be in equilibrium if the stream's power is equally distributed along its course, and the product of slope and discharge is equal in all the reaches (Leopold et al. 1953). Such rivers are also designated by the term "graded streams". Longitudinal profiles of graded streams are often considered to be smooth, convex upward curves, that is, curves that decrease systematically in slope in down valley direction (Mackin 1948).
Hack (1973) developed a quantitative geomorphic parameter, the stream gradient index (SL), which describes the relative steepness of an actual river profile at a point. Variations in the stream gradient index along a river channel profile reflect abrupt changes in slope and therefore disequilibria in the bedrock channel profile, which may be caused by lithological variation (Hack 1973; McKeown et al. 1988), local deformation (Burnett and Schumm 1983; Keller and Rockwell 1984; McKeown et al. 1988; Ramírez-Herrera 1998), or surface uplift (Reed 1981; Seeber and Gornitz 1983; Nott et al. 1996; Goldrick and Bishop 1995; Seidl et al. 1996; Weissel and Seidl 1998; Bishop et al. 2005). High values of SL are indicative of highly tilted slopes along the river profiles.

\section{Geological setting}

Owing to the excellent outcrop conditions provided by the deep incision of rivers, the Central Andes of Peru are particularly well suited to get insight into the internal structure of this morphologically majestic orogen. The Peruvian Andes display three outstanding geomorphic features (Fig. 1). Two major mountain ranges, the Eastern and Western Cordillera, run parallel to the coast and are separated by the Central Highlands, which correspond to a high plateau with a mean elevation of $4,000 \mathrm{~m}$ and low local relief. To the SE, the Central Highlands broaden into the Altiplano of Bolivia, whereas to the NW, they taper out near Cerro de Pasco well above 4,000 m a.s.l.

The Western Cordillera comprises a chain of peaks reaching altitudes of $5,000-7,000 \mathrm{~m}$. Local relief is very high owing to dissection by numerous streams, most of which flow perpendicular to the chain. In contrast to the Northern and Southern Andes of Ecuador and Chile, where the highest peaks are volcanoes, sedimentary and igneous rocks uplifted to high altitudes are the backbone of the Western Cordillera in the Central Andes of Peru.

In the Eastern Cordillera, many of the higher peaks are built of crystalline basement uplifted along steeply dipping strike slip faults with reverse component. These high peaks are located in the west of this cordillera. Consequently, local relief is high in the west and diminishes eastward in the Subandean Zone. Nevertheless, certain reaches of rivers in the Eastern Cordillera are also deeply incised. The general courses of these rivers contain segments parallel to the chain.

The structures of the Peruvian Andes have a general NW-SE trend (Fig. 2). They are of compressional style but include strike slip components. The Jurassic and Early Cretaceous strata of the coastal area of the Western Cordillera are gently folded and faulted, folds being open with axes trending nearly north-south (Atherton and Webb 
1989). The granodiorites and tonalites of the Coastal Batholith that intruded these folded strata lack any internal deformation. The Marañon thrust belt in the central and eastern part of this cordillera contains tightly folded Cretaceous strata in the west. The axial surfaces are vertical and fold axes trend NNW-SSE, parallel to the major thrust faults (Fig. 2; see also Wilson 1963; Mégard 1978, 1984). Toward the east, the Central Highlands, the folds become more open and are verging to the NE. The fold style reflects the thick Jurassic carbonates that appear at the surface. The Marañon thrust belt has been intruded by Cenozoic granitoids. Many of the plutons are located in the core of anticlines. The Cenozoic volcanics overlying the thrust belt are subhorizontal. Local mild deformation is indicated by tilted lava flows. Toward the Pacific coast, these volcanics are dipping to the WSW. This dip is caused by later deformation (Quechua Phase) in some instances, but may be a primary volcanic structure in other cases.

The Central Highland is a plateau where Paleozoic and Mesozoic strata display folds and steep faults. The folds within the Mesozoic strata are open and represent a continuation of the Marañon thrust belt. Steep faults juxtapose locally Paleozoic strata to these folds (Fig. 2). The Paleozoic, Devonian to Permian strata are also openly folded with steep faults cutting the folds. These faults are likely to have a strike slip component as well. Axial surfaces of folds and faults generally strike NNW-SSE (Fig. 2).

The Eastern Cordillera contains Neoproterozoic crystalline basement within its core, which is overlain by Paleozoic sediments. In the very central part of the Peruvian Andes, Late Paleozoic strata directly overly the crystalline basement, while to the SE, in the Cusco area,
Fig. 2 Generalized geological map of the Peruvian Andes showing main lithologies and major thrust faults. Thrust faults mark the base of the eastern escarpment of the Eastern Cordillera. The Coast Batholith outcrops along the western escarpment of the Western Cordillera

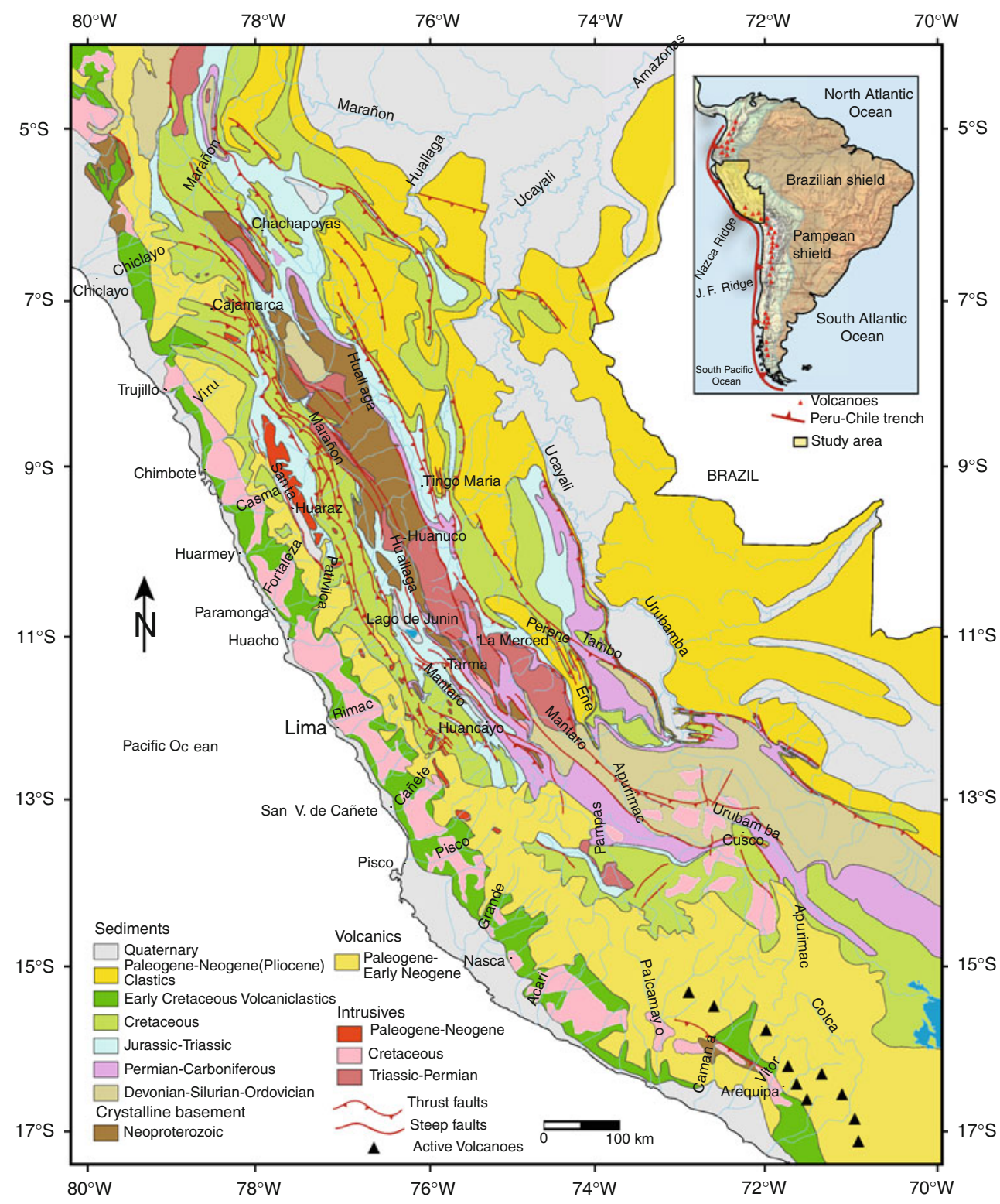


Ordovician to Devonian strata are present as well. The folded Paleozoic strata are intruded by Permotriassic granitoids. Subvertical faults put the crystalline basement in contact with Late Paleozoic sediments. These steeply dipping reverse faults also contain a strike slip component and strike in a NNW-SSE direction parallel to the cordillera. The Subandean thrust belt in the eastern part of the Eastern Cordillera is a fold-and-thrust belt involving Cenozoic sediments as young as Pliocene in age. The overall architecture is characterized by east directed imbricate thrusting. The major thrust faults are subparallel to the orogen with local splaying and rejoining bends giving a more curved nature compared to the steep faults in the interior of the Andes (Fig. 2).

\section{Drainage pattern of the Peruvian Andes}

The analysis of fluvial networks allows getting information regarding how drainage patterns and bedrock channel profiles relate to tectonics, rock-uplift, climate, and surfaces processes. In this study, the observation of the drainage pattern and river profiles concentrates on the comparison with the geological structure of the Peruvian Andes. Two important drainage basins exist: the Pacific Basin in the Western Cordillera and the Amazonas Basin in the Central Highlands and the Eastern Cordillera (Fig. 1). The water divide between the basins that follows the crest of the Western Cordillera. The Amazonas Basin consists of three sub-basins, the Mantaro, Urubamba and Huallaga drainage basins. Rio Huallaga and Rio Mantaro have their sources in the vicinity of Laguna de Junin, at the NW termination of the Central Highlands near Cerro de Pasco. The Pacific Basin consists of a large number of sub-basins similar in size and arranged in a regular fashion along the Pacific coast.

The length of the main rivers of the Pacific Basin draining the western escarpment of the Andes varies between 150 and $350 \mathrm{~km}$; rivers have relatively straight courses across the Western Cordillera and flow on barren bedrock (Fig. 3). The bed-channel slopes are steep and lack indications of sediment accumulation along their courses. The rivers thus display active erosion and incision and may be classified as bedrock-channeled rivers (Keller and Pinter 1996; Whipley 2004). The transported bed load is deposited in the lowlands close to the Pacific coast. These rivers flow over the Cretaceous strata of the Marañon thrust belt and Cenozoic volcanics in their upper reaches, whereas in their lower reaches, they are incised into the Coastal Batholith and Cretaceous volcaniclastics (Fig. 2). As an exception Rio Santa, located in NW Peru, flows parallel to the coast in its upper reach following a major fault zone between the Cordillera Blanca and Cordillera Negra.

Rivers draining the eastern escarpment of the Andes are 200-800 km long upward of the confluence with Rio Amazonas. These rivers differ from those described earlier by flowing parallel to the orogen over considerable distances in both a SE and a NW direction. The major tributaries of these rivers have their sources in the Western Cordillera or in the Central Highlands. The segments where the main rivers flow across the range are characterized by deep incision (see Figs. 4, 5). At the eastern margin of the Eastern Cordillera, these rivers become meandering and can be classified as alluvial rivers, in which agradation is high. Figure 6 shows the confluence of Rio Ene and Perene into Rio Tambo. Rio Tambo flows to the southeast parallel to the Tambo fault system at the foot of the Otishi Cordillera. This cordillera was uplifted in the hanging wall of the Tambo thrust faults and displaced the river to the northeast. Similar observations hold for other river segments of the Subandean thrust belt, which had their courses constrained by the tilted strata in the hanging wall of thrust faults (Fig. 2).

\section{Longitudinal river profiles}

Patterns and slopes of river channels are susceptible to changes in bedrock resistance and tectonic events.
Fig. 3 Valley with steep slopes and active bedrock incision in the Pacific Basin. a Rio Santa cutting into tilted Early Cretaceous sandstones. b Rio Cañete cutting into an Early Cretaceous sandstone-shale sequence

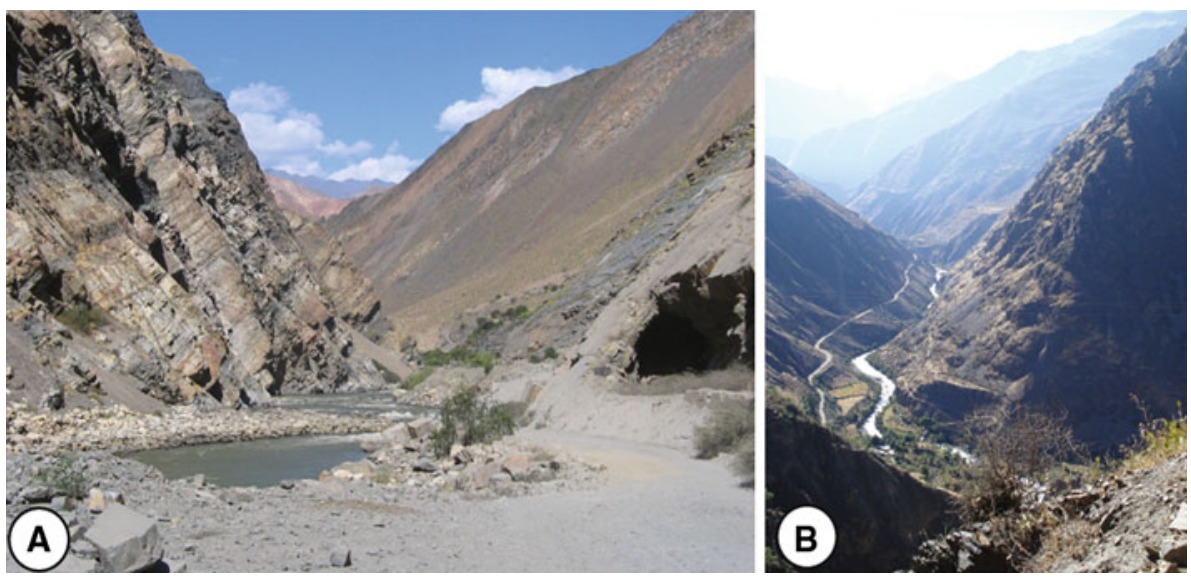




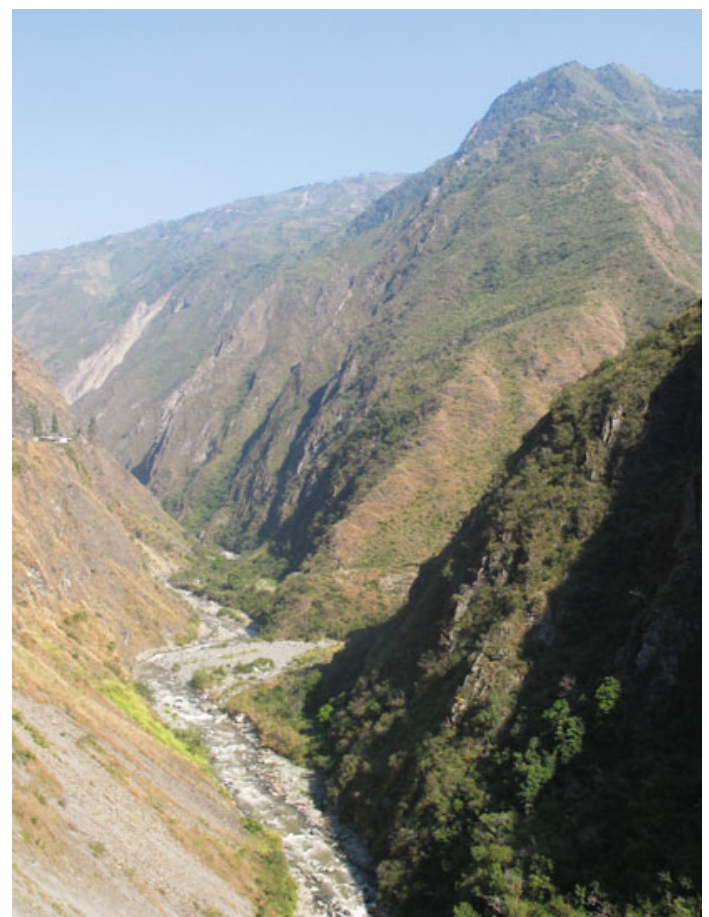

Fig. 4 Valley with steep slopes and active bedrock incision in the Amazonas Basin. Rio Perene is cutting into crystalline basement rocks

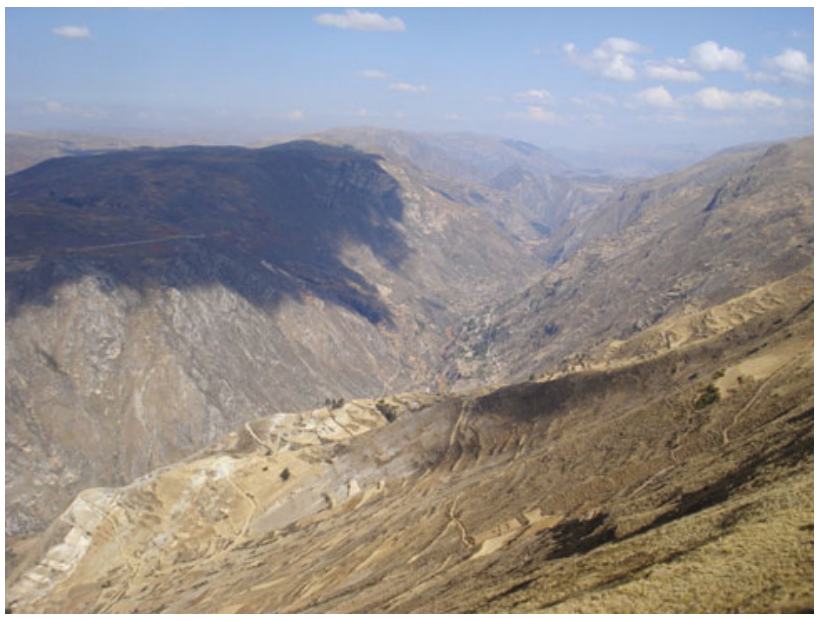

Fig. 5 Canyon incised by Rio Mantaro into Jurassic sediments of the Central Highlands

Numerous studies underline the usefulness of bedrock longitudinal profiles of rivers as tool for the analysis of landscapes (Goldrick and Bishop 2007 and references therein). Leopold and Maddok (1953) proposed the concept of the equilibrium bedrock channel profile or the graded river, which postulates that for a graded river, the slope and channel characteristics are delicately adjusted to provide, with available discharge, just the velocity required for the transportation of the bed load supplied from the drainage

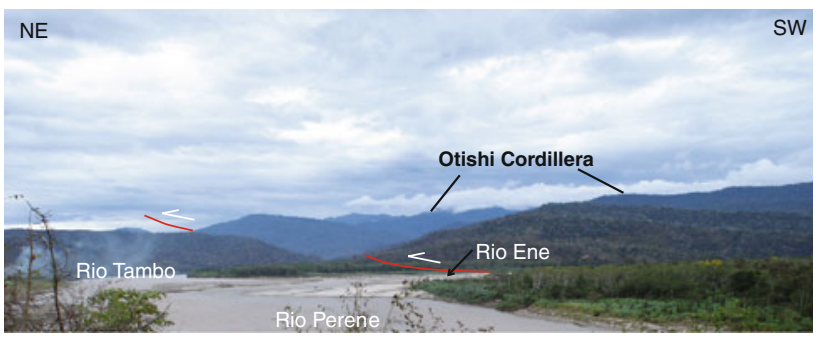

Fig. 6 Confluence of Rio Ene and Rio Perene into Rio Tambo. The Otishi Cordillera to the right and the background is uplifted by the thrust faults of the Tambo fault system of the Subandean thrust belt. Rio Tambo flows to the south-east through the gap in the center of the photograph and then parallel to the foot of the Otishi Cordillera in the background

basin. The longitudinal profile shape of these channels is a smooth convex upward curve (see Fig. 7a) that decreases systematically in slope in down valley direction (Mackin 1948). Response of the rivers to tectonic disturbances that change the channel slope and create a disequilibrium state is to re-establish the equilibrium shape. In this paper, we are interested in the relationship between shape of the bedrock channels of the Peruvian rivers on one hand and the bedrock lithology and tectonic movements on the other hand. The longitudinal river profiles were constructed using 1:500,000 topographic maps.

Longitudinal channel-river profiles in the Pacific Basin are shown in Fig. 7b. Generally speaking a convex upward shape prevails in the lower reaches, but Rio Santa has a more linear profile, and Rio Colca and to some degree Rio Cañete and Catahuasi are concave upward in their upper reaches. In the coastal area, rivers flowing across a broad belt of Pleistocene deposits, show low gradients (Rio Chiclayo and Rio Grande in Fig. 7), whereas higher gradients are typical where bedrock is exposed close to the Pacific shore (Rio Pativilca in Fig. 8).

All the major rivers of the Pacific Basin flow over the folded Mesozoic limestones and sandstones of the Marañon fold-and-thrust belt and the overlying Cenozoic volcanics of the Western Cordillera. Downstream, the rivers cut through the undeformed Coastal Batholith and the slightly deformed Mesozoic strata of the Coastal Area (Fig. 2). As can be seen in the river profiles in Fig. 8, breaks in slope (or knick points) of the river channels do not correlate with abrupt changes in bedrock lithology. This is in contrast to the finding of Abbühl et al. (in press) who report a correlation of knick zones to the contact to a "cap rock" made of Cenozoic volcanics for Rio Piura (located north of our study area), Rio Pisco (within our study area) and Rio Lluta (south of our study area). The volcanic rocks in our study area outcrop in various parts of the rivers, and their nature and orientation are not in concert with the notion of a "cap rock". 
A

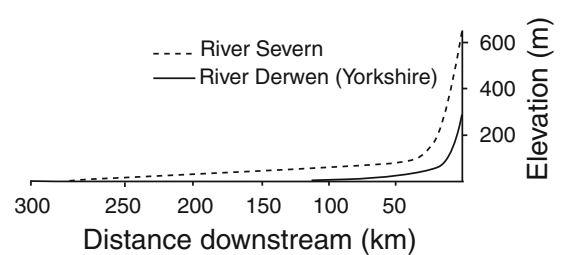

B
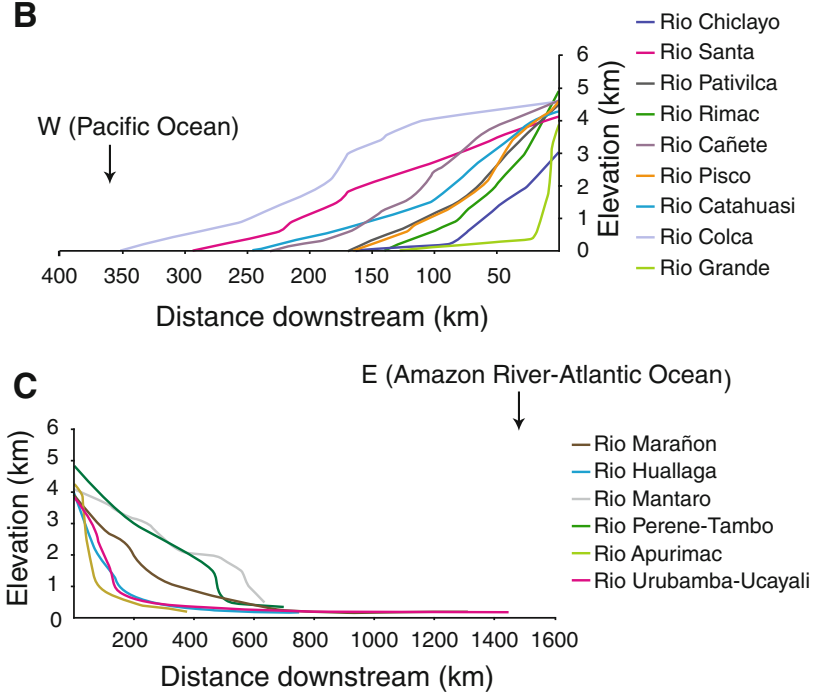

Fig. 7 a Equilibrium longitudinal profiles of two rivers in Great Britain. The concave upward shapes of these profiles are characteristic of most graded rivers (taken from Keller and Pinter 1996). b Longitudinal profiles of a selection of rivers of the Pacific Basin of Peru, plotted downstream from the source. $\mathbf{c}$ Longitudinal profiles of a selection of rivers of the Amazonas Basin of Peru, plotted downstream from the source

East of the continental divide, the Rio Marañon and the Rio Huallaga Basins are draining into Rio Amazonas. Rio Marañon has its source in the vicinity of Cerro de Pasco in the NW termination of the Central Highlands (Fig. 2). It first flows to the NNW in a deep valley between the Central and Western Cordillera and follows more or less the contact between crystalline basement of the Eastern Cordillera (the so-called Marañon massif) and the Mesozoic of the Marañon fold-and-thrust belt. This contact is marked by major faults uplifting the crystalline basement rocks and seemingly controlled the drainage pattern. The river profile (Fig. 9a) exhibits a steep slope in this orogen-parallel segment but attains a shallower dip just before the river changes direction to an easterly flow across the Eastern Cordillera and the Subandean thrust belt. The river finally becomes very flat downstream in this thrust belt.

The Rio Huallaga longitudinal river profile (Fig. 9b) is similar, with a steep slope at the source and across the Marañon massif. Near Huanuco, the river turns to the east cutting these structures and maintaining the steep gradient. The river then turns to the NNW and parallel to the orogen once again. The gradient becomes shallower and remains so even after the river turns to the NE cutting across the structures of the Subandean thrust belt. The lowermost reach, located outside this thrust belt, is characterized by a very low gradient.

Rio Mantaro in central Peru (Fig. 9c) flows parallel to the orogen but changes its course twice by nearly $180^{\circ}$. In the upper reach, the rivers flow toward the SSE within the Central Highland. An abrupt increase in the channel gradient occurs near Huancayo within the Late Paleozoic sediments. The high gradient persists around the $180^{\circ}$ turn the river makes to flow toward the NNW. Another abrupt increase in slope occurs after the second bend of the river. But where Rio Mantaro crosses an important thrust fault putting Paleozoic sediments and Triassic granitoids of the Eastern Cordillera onto Cenozoic sediments of the Subandean thrust belt, the gradient decreases and remains low down to the confluence with Rio Apurimac.

Rio Apurimac (see Fig. 9d) has a relatively steep gradient in the upper reach. However, a steep gradient is observed just upstream of a major thrust fault within the Paleozoic sediments. A low gradient persists downstream of this thrust fault and the confluence with Rio Mantaro, where the river changes name from Apurimac to Ene.

Rio Perene and its tributaries incised the Neoproterozoic metamorphic crystalline basement and the Triassic intrusions of the Eastern Cordillera (Fig. 9e). In the upper reach, the channel gradient is extremely steep and decreases downstream where it cuts an important thrust fault putting Triassic intrusives onto Cretaceous sediments. The gradient remains moderate across a series of less important thrust faults all the way to the confluence with Rio Ene. From this confluence on the river carries the name Rio Tambo. The gradient diminishes once Rio Tambo reaches Rio Ucayali.

Rio Urubamba displays a concave upward longitudinal profile in the headwaters (see Fig. 9f), where it flows over Early Paleozoic metamorphosed sediments and Late Paleozoic volcanics. Within the Early Paleozoic rocks, which are affected by thrust faulting and vertical faulting, the river profile shows an extremely steep gradient (Fig. 9f). Further downstream, the gradient diminishes and is low at the confluence with Rio Tambo, from where on this river carries the name of Rio Ucayali. Rio Ucayali is an alluvial river with a very low gradient and flows parallel to the fold and thrust structures within the Neogene sediments of the Subandean thrust belt. From the confluence with Rio Marañon on, the river becomes the Rio Amazonas.

In contrast to the rivers of the Pacific Basin, the rivers that drain the Amazonas Basin show abrupt gradient changes where the river crosses important thrust faults (i.e., thrust faults with a large displacement). The high gradients upstream of these thrust faults seem to indicate a close relationship between channel gradient and thrust tectonics. To pursue this question in more detail, we expanded the analysis to cover the entire Andean chain and to produce a 


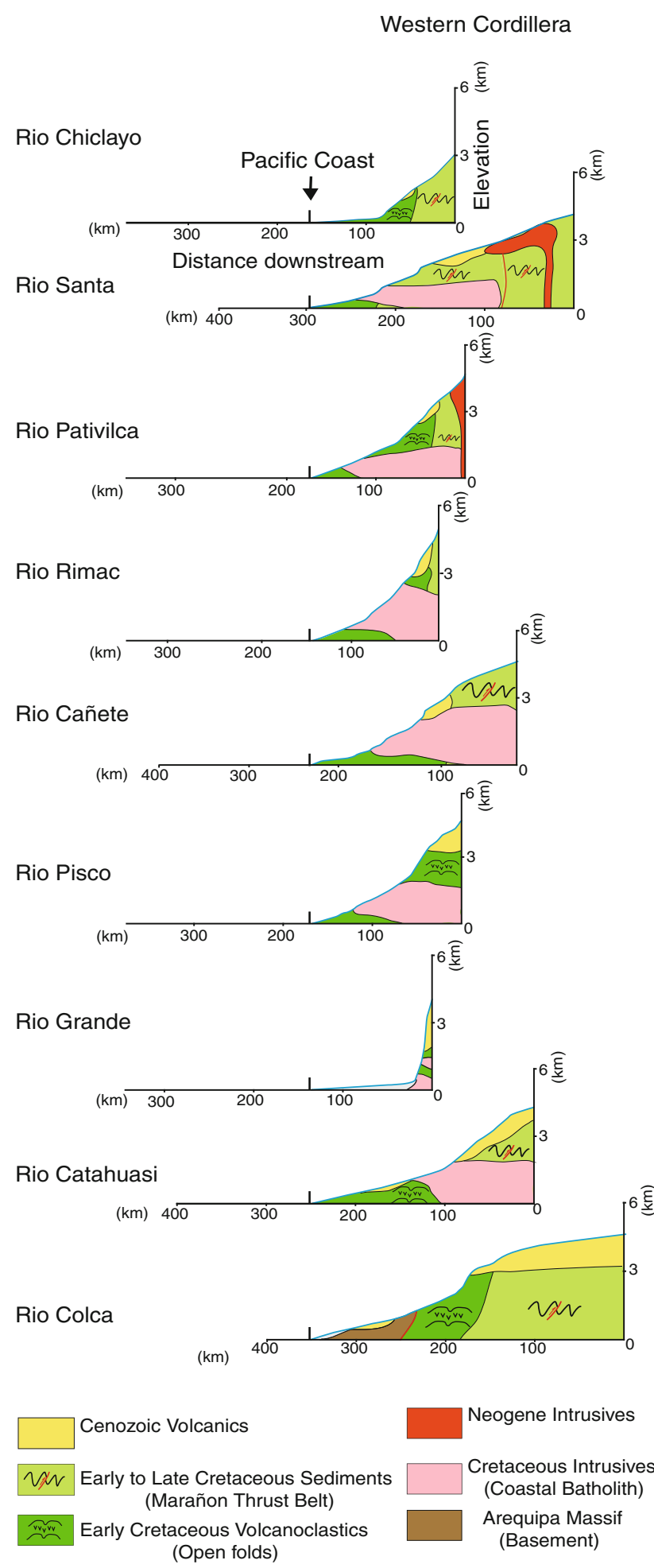

Fig. 8 Longitudinal river profiles of the Pacific Basin including information on bedrock geology. The rivers flow across the Marañon Thrust Belt, Cenozoic volcanics, the Coastal Batholith and an Early Cretaceous volcaniclastic sequence. Breaks in slope do not coincide with changes in lithology of the river channel or structural features map of a suitable parameter including channel gradients. Our choice fell on stream gradient indices, which will be discussed in the following section.

Stream gradient indices

The concept of stream gradient index introduced by Hack (1973) combines the channel gradient at a point and the length of the river channel, which correlates with water discharge. The stream gradient index may thus be seen as a proxy for stream power or competence. The stream gradient index has been widely used in later works to determine the relation of the measured data to the lithological variation of the bed rock channel (Hack 1973; McKeown et al. 1988), to local deformation (Burnett and Schumm 1983; Keller and Rockwell 1984; McKeown et al. 1988; Ramírez-Herrera 1998), or to surface uplift (Reed 1981; Seeber and Gornitz 1983; Nott et al. 1996; Goldrick and Bishop 1995; Seidl et al. 1996; Weissel and Seidl 1998; Bishop et al. 2005). A summary of these works can be found in the study by Goldrick and Bishop (2007).

The stream gradient index was defined from the profile equation (Hack 1973) of a graded river with logarithmic horizontal scale (see Fig. 10):

$H=\boldsymbol{k} \ln L+c$

Here $H$ is the altitude at a point on the profile, $L$ is stream length measured from the drainage divide along the channel to the same point on the principal stream, and $C$ and $\boldsymbol{k}$ are constants. The derivative of Eq. 1 with respect to $L$ yields

$\mathrm{d} H / \mathrm{d} L=\mathrm{d}(\boldsymbol{k} \ln (L)) / \mathrm{d} L=\boldsymbol{k} / L$

In Eq. $2, \mathrm{~d} h / \mathrm{d} L$ corresponds to the river channel slope $S$ at a point and $\boldsymbol{k}$ defines the steepness of the channel on a semilogarithmic plot (Fig. 10). $\boldsymbol{k}$ itself is the definition of stream gradient index and can be expressed as:

$\boldsymbol{k}=L(\Delta H / \Delta L) \quad$ or $\quad \boldsymbol{k}=L\left(H_{j}-H_{i} / L_{j}-L_{i}\right)$

In Eq. 3, $L$ is the stream length measured from the source on the drainage divide to the point of interest along the longest channel in the drainage basin. $\Delta H$ is the difference in elevation and $\Delta L$ the length between the ends of the segment considered. In this work, the calculations of the stream gradient indices in the Peruvian rivers were carried out as is shown in Fig. 11, using 1:500,000 topographic maps. The base level of the profiles in the Pacific Basin is sea level (Pacific Ocean) and for the Amazonas Basin the altitude of the confluence of Rio Marañon and Ucayali, the starting point of the Rio Amazonas. The stream gradient index was calculated for all of the main rivers and tributaries in the two basins. From the individual data points, contour lines were determined. 


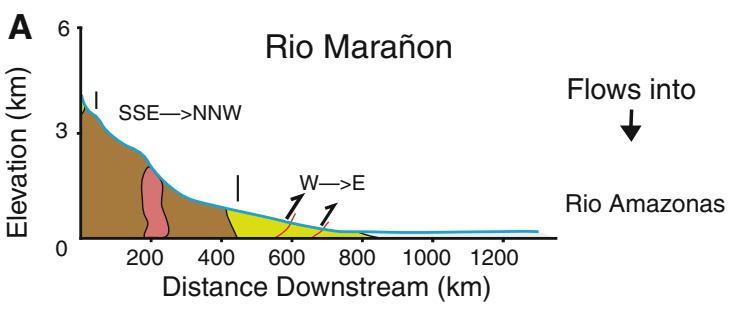

B
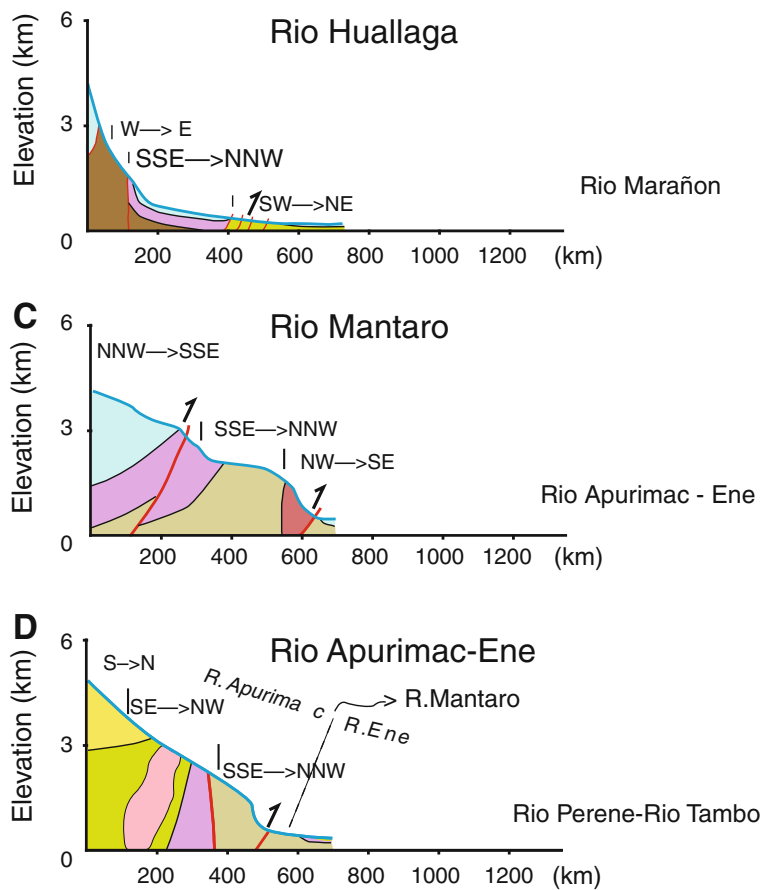

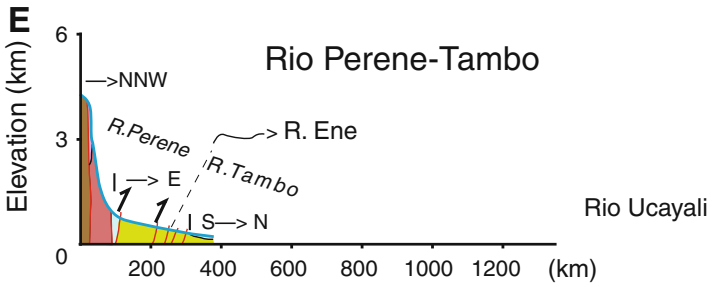
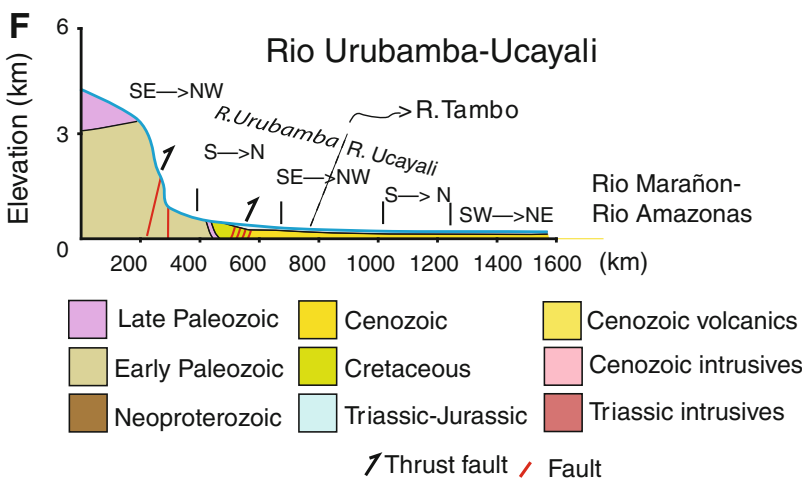

Fig. 9 Longitudinal river profiles of the Amazonas Basin including information on bedrock geology. The rivers flow over crystalline basement rocks, Paleozoic and Mesozoic sedimentary sequences and Cenozoic strata. Changes in slope are observed where the rivers cross thrust faults

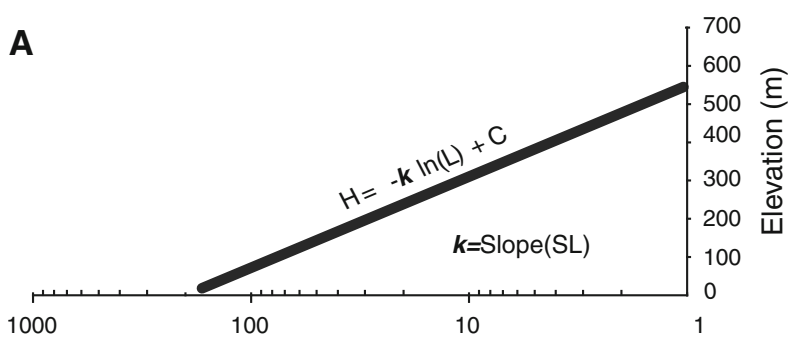

Distance Downstream(log $L)(\mathrm{km})$

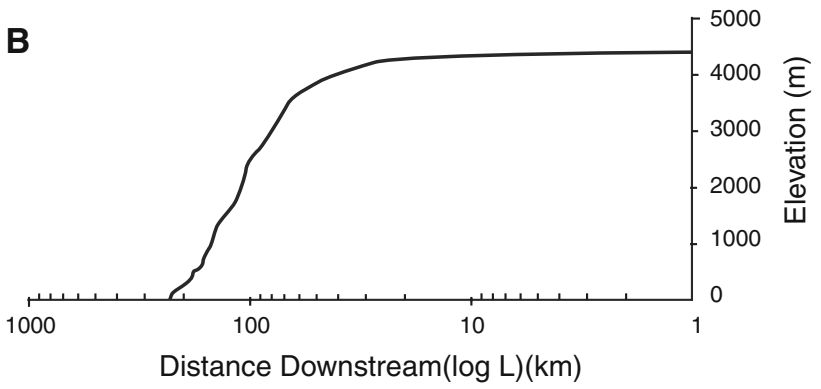

Fig. 10 Semi-logarithmic plot of river profiles. a The logarithmic plot of a graded river profile, an straight line according to Hack equation, where $H$ is the elevation, $L$ the length of the downstream distances and $C$ is a constant and $k$ is the slope of the line. b Semilogarithmic profile of Rio Cañete of the Pacific Basin. Obviously, the profile is concave upward and the river may consequently not be considered as being graded

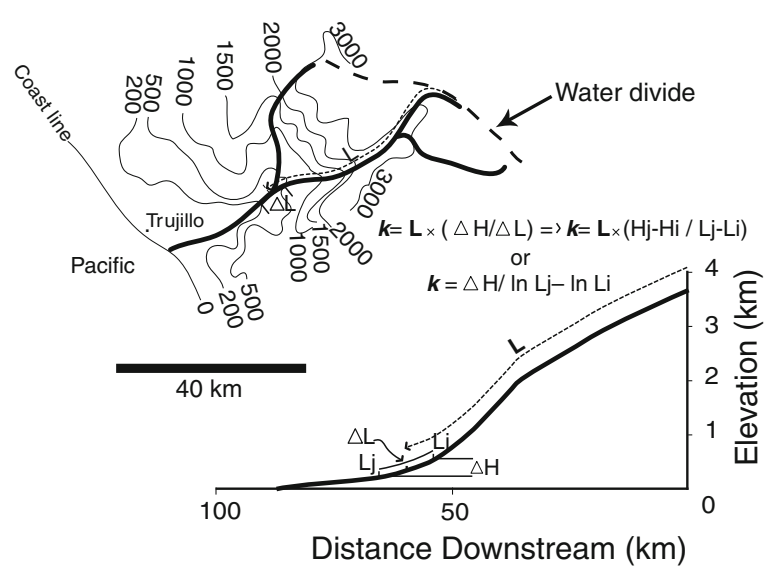

Fig. 11 Illustration of the parameters used to calculate the gradient indices. The definition of the components is given in the text

The result is shown in the stream gradient contour map in Fig. 12. As might be expected, low index values $(<1,000)$ are encountered throughout the source area of the various rivers. The values then increase in downstream direction toward the Pacific Ocean and Rio Amazonas. A marked zone of very high values $(>2,000$, locally $>3,000)$ obtained from the rivers flowing west into the Pacific forms a band parallel to the Pacific coast the intermediate parts of these rivers. A comparison between the geological map 
Fig. 12 Contour map of stream gradient indices of the Peruvian Andes. Two belts of high values (2,000-3,000 and more) straddle the western escarpment of the Western Cordillera and the eastern escarpment of the Eastern Cordillera

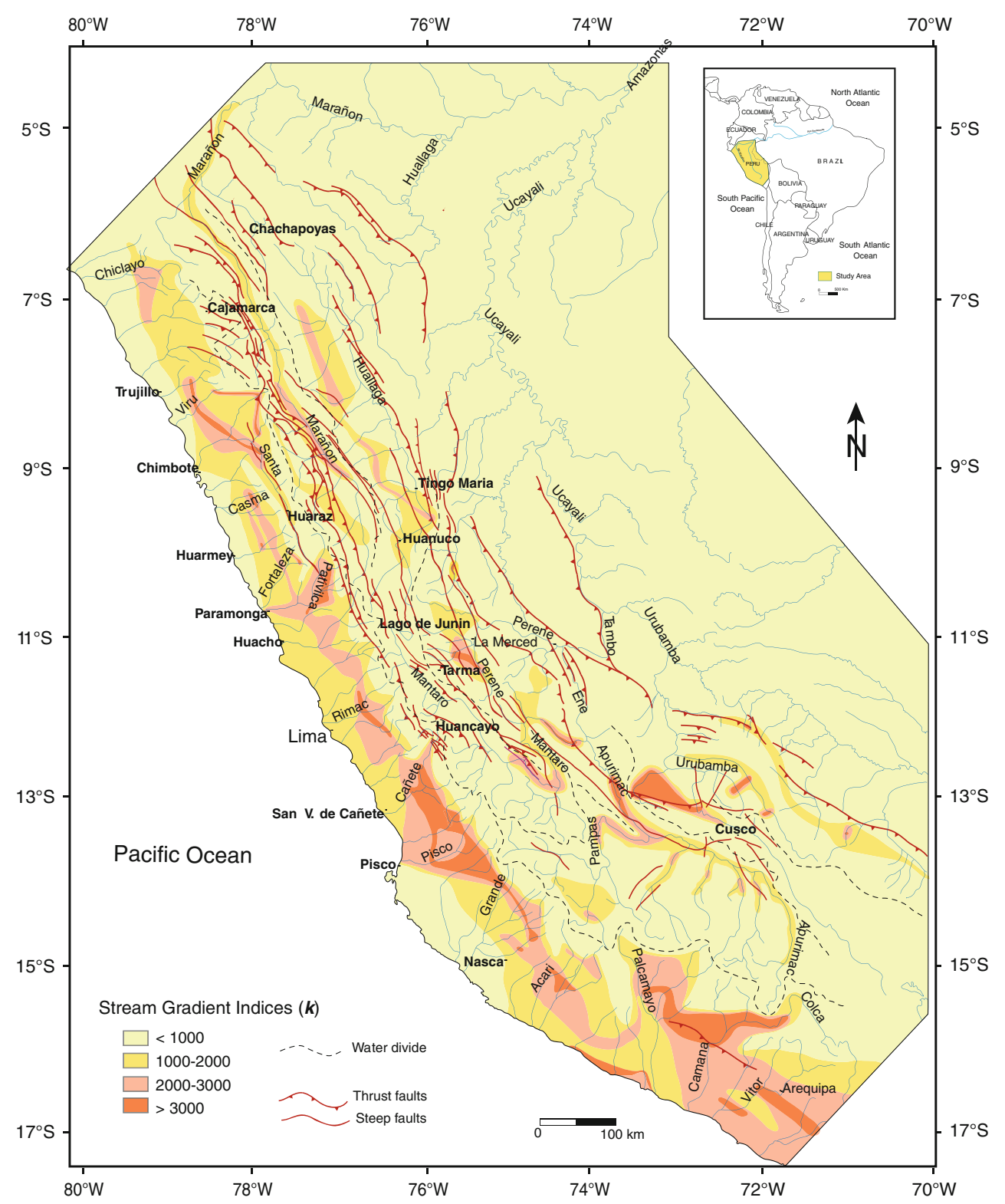

In some instances, high index values occur where the rivers change their course from orogen-parallel to crossing the Eastern Cordillera. The lowest stream gradient index values are observed in the lowlands of the Subandean thrust belt where the rivers flow mainly parallel to the folds and thrust faults of this zone. But even where they flow across thrust faults, no significant change in gradient or index value could be observed.

\section{Large-scale morphology of the Central Andes}

The three principal geomorphic features of the Peruvian Andes, Western Cordillera, Central Highland and Eastern Cordillera are each characterized by a particular morphology. The Central Highland located between the two 
cordilleras is about $50 \mathrm{~km}$ wide and extends from Lago de Junin to the SE over a distance of more than $300 \mathrm{~km}$. In the $\mathrm{SE}$, it widens into the Altiplano of Bolivia. The Central Highland is made of Paleozoic and Mesozoic sediments that are folded and faulted. However, these structures did seemingly not have any significant impact on the local relief. There are no prominent peaks within this plateau, and local relief at the $10 \mathrm{~km}$ scale is typically not larger than $1,500 \mathrm{~m}$. The Central Highland with a mean altitude of about $4.000 \mathrm{~m}$ above sea level is locally dissected by the headwaters of the rivers of the Amazonas Basin (Rios Huallaga, Mantaro and Apurimac to name the most important ones).

In contrast to the Central Highland, there is a row of peaks reaching more than $6,000 \mathrm{~m}$ in altitude marking the backbone of the Western Cordillera and defining the water divide between the Pacific and the Amazonas Basins. In the north, near the city of Huaraz, the peaks of the Cordillera Blanca are made of Jurassic and Early Cretaceous sediments of the Marañon Thrust Belt that were intruded by the Cordillera Blanca batholith. The summits in the Cordillera Blanca reach higher than $6,000 \mathrm{~m}(6,768 \mathrm{~m}$ for the highest, Huascaran) and local relief at the $10 \mathrm{~km}$ scale exceeds 3,000 m. The photograph in Fig. 13a gives an impression of the rugged relief of this range. The Cordillera Blanca batholith intruded in Miocene times (8.2 Ma according to McNulty et al. 1998). Cooling of the batholith from $500^{\circ}$ to $300^{\circ} \mathrm{C}$ occurred in the time window of 5-3 Ma (Petford and Atherton 1992). Some of the uplift is associated with a
W dipping shear zone outcropping in the $\mathrm{W}$ of the batholith (Rousse et al. 2003) that has been interpreted as a low angle detachment fault by McNulty and Farber (2002) and named "Cordillera Blanca detachment fault". Our own observations suggest that the Cordillera Blanca was uplifted relative to the neighboring Cordillera Negra to the west along a subvertical fault running parallel to the range and beautifully exposed at Lago Querococha (E of Recuay) where subvertical slickensides indicate the shear sense (see Fig. 13b). This fault is still active as is indicated by fault scarps in Quaternary fluvial cones (Fig. 13c). We suspect that the "Cordillera Blanca detachment fault" is related to the emplacement of the pluton and comparable to structures such as know, e.g., in the Alps ("Pedra Rossa shear zone" of Berger et al. 1996 in the roof of the Bergell pluton). The cross-section shown in Fig. 13d shows the structural relation between the Cordillera Blanca and Negra and underlines the importance of reverse faulting on the development of the youthful landform of the Cordillera Blanca. A number of high ranges characterize the Western Cordillera of Central Peru. These ranges are part of the Marañon thrust belt, a fold-and-thrust belt made of Jurassic and Cretaceous sediments that formed by east verging thrusting in Paleocene to Eocene times (Incaic Phase). In the Huayhuash and Raura ranges located just south of the Cordillera Blanca, the highest summits reach 6,634 and $4,766 \mathrm{~m}$ a.s.l., respectively, and local relief at the $10 \mathrm{~km}$ scale is typically of the order of $2,000-3,000 \mathrm{~m}$. In this part of the Peruvian Andes, the Western and Eastern Cordilleras
Fig. 13 Young uplift of the Cordillera Blanca (northern Peru). a Photograph showing geomorphic expression of the young uplift; view is from the Cordillera Negra across Huaraz to the east. b Steeply dipping, uneven fault plane with subvertical slickensides indicating uplift of the Cordillera Blanca block relative to the Cordillera Negra block; fault strike is NNW-SSE. c Photograph showing fluvial fan offset by a recent fault (white arrow); fault strike is NNW-SSE; view is toward Cordillera Blanca. d Schematic cross section showing the geometry of reverse faulting responsible for the uplift of the Cordillera Blanca; line of section passes just north of Huaraz
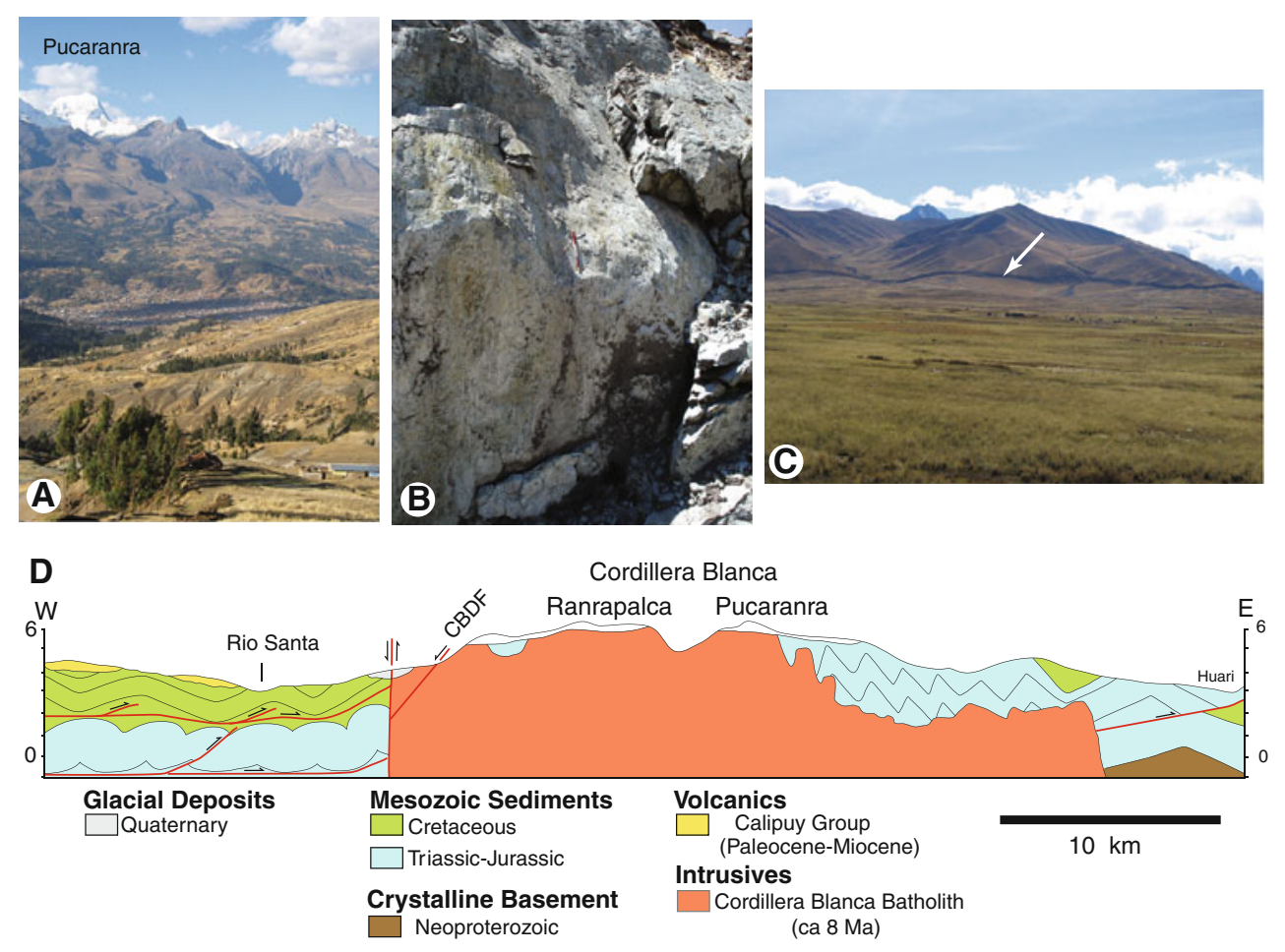
are juxtaposed, separated by the Rio Huallaga valley. Farther south, in the central part of the Western Cordillera, the Yauyos range is built essentially of Late Cretaceous sediments. Here, thrusting uplifted the Cretaceous strata by about $1,350 \mathrm{~m}$ relative to the Central Highland. The highest peaks of this range reach $5,817 \mathrm{~m}$ and the local relief at the $10 \mathrm{~km}$ scale exceeds $3,000 \mathrm{~m}$ owing to the deep incision by the rivers of the Pacific Basin. In case of the Abra la Viuda, located on the water divide west of Lago de Junin, a range consisting of Early Cretaceous strata forms local summits as high as $5,500 \mathrm{~m}$ that tower the Central Highland, which is at an altitude of 4,000-4,500 m (see Fig. 14a). This local topographic relief is the result of Quechua Phase thrusting putting Early Cretaceous strata onto Oligocene volcanics in Miocene times. As is evident from the cross-section of Fig. 14b, Quechua thrusting raised the Cretaceous strata by about $1,500 \mathrm{~m}$, an amount comparable to the local relief at the $10-\mathrm{km}$ scale. In SE Peru in the Chilca and Ampato ranges near Arequipa, most of the rock types encountered in the Western Cordillera are volcanics. The highest peaks are active volcanoes and reach an altitude of more than $6,000 \mathrm{~m}$.

Summarizing, the highest peaks in much of the Western Cordillera are formed by sedimentary strata uplifted by thrusting in Cenozoic times. With the exception of the Arequipa region, active volcanoes are missing, unlike the situation in the neighboring Northern Andes of Ecuador

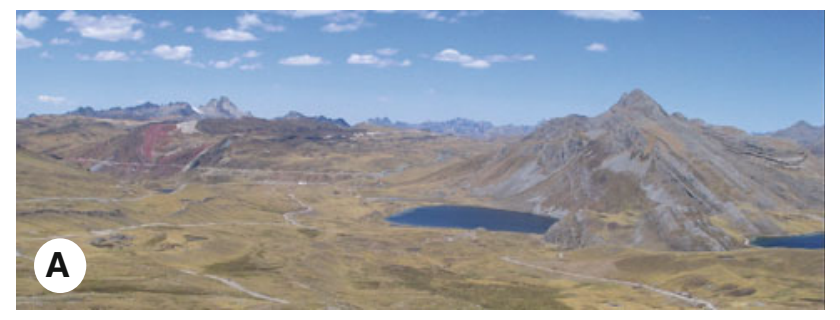

B

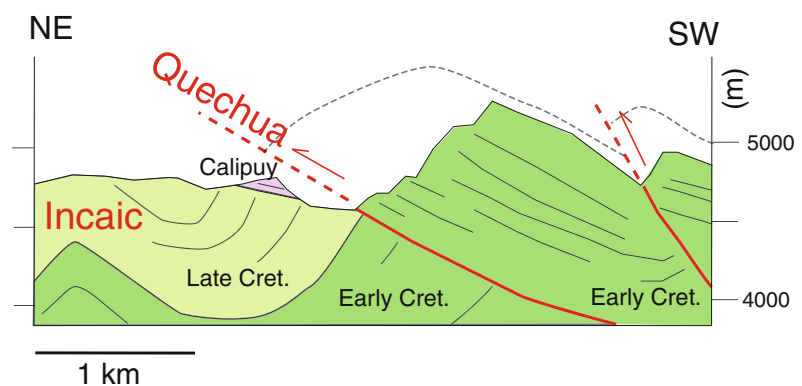

Fig. 14 Morphologic expression of Neogene thrusting (Quechua Phase) in the Central Highlands and Western Cordillera (near Abra la Viuda). a Photograph showing upthrusted Early Cretaceous strata forming a questa pertaining to the Western Cordillera. The Late Cretaceous red beds (Capas rojas) to the left show a syncline caped by Oligocene volcanics (Calipuy group) within the Central Highlands. b Schematic cross section showing the geometry of thrusting responsible for the uplift of the Early Cretaceous strata and the Southern Andes of Bolivia-Chile. The lack of recent volcanism in the Central Andes is explained by the shallow dip of the subduction zone beneath Peru (e.g., Jaillard et al. 2000), a point that will be further discussed by Gonzalez (2011) and Gonzalez and Pfiffner (in prep).

Within the Eastern Cordillera, the highest peaks reach around $6,000 \mathrm{~m}$, and they are built of crystalline basement rocks or Paleozoic metamorphic sediments. These rocks have been affected by thrusting and reverse slip faulting along subvertical faults. In the central part of the Eastern Cordillera, near Huancayo, the Nevado Huaytapallana, made of crystalline basement, reaches an altitude of $5,780 \mathrm{~m}$. The uplift occurred along a vertical fault putting crystalline basement next to nonmetamorphic Permian strata. The age of this fault is hitherto unknown. Local relief at the $10-\mathrm{km}$ scale in this chain amounts to $3,000 \mathrm{~m}$ and more. In the southern part of the Eastern Cordillera, near Cuzco, snow peaks within the Vilcabama and Vilcanota ranges made of folded and faulted Early Paleozoic strata are higher than $6,000 \mathrm{~m}$, and local relief at the $10-\mathrm{km}$ scale is in many instances larger than $3,000 \mathrm{~m}$.

The eastern escarpment of the Eastern Cordillera grades into the Subandean thrust belt, an east verging thrust belt that involves Paleozoic to Cenozoic sediments and which recorded the latest, Neogene events of deformation. Uplifted foothills reach 2,000 $\mathrm{m}$ in altitude and are quite clearly related to thrusting, for example, the Shira Mountains are bordered by a thrust fault in the east (the Tambo thrust) and thrusting obviously influenced the course of Rio Ucayali, which was shifted eastward in the process of thrust related uplift. The youngest deformation front is located in the lowlands of the Amazonas Basin, Here, despite thrusting and gentle folding affecting both, the crystalline basement and the Cenozoic sedimentary cover, no prominent morphologic features are discernible.

\section{Discussion}

The presence of mountain ranges with high summits and rugged morphology has inspired a number of geologists to think about mountain building processes. The growth and decay of local relief combined with the increase and decrease of altitudes of summits and main valley floors were explained by various models of tectonic forcing (rock uplift) and the ensuing response of surface processes (erosion). A summary discussion of this subject is given by Summerfield (1991) and Burbank and Anderson (2001). In the case of the Andes of Peru, a mountain range of high elevation formed in response to the convergence of an oceanic and a continental plate that was characterized by changing convergence direction, convergence rate and absolute plate motions (Pardo-Casas and Molnar 1987, 
Silver et al. 1998; Jaillard et al. 2000, Steinberger and Torsvik 2008). The uplift history of the Central and Northern Andes as determined from paleobotanical and landscape development has been reviewed by Gregory-Wodzicki (2000). According to this review, the Altiplano-Puna region (and consequently the Central Highland in Peru) experienced a surface uplift of 2,300-3,400 $\mathrm{m}$ during the past 10.7 million years (since the Late Miocene). This time span includes Quechua Phase thrusting as recorded in the Subandean thrust belt and, as shown in this paper for the first time, in the Western Cordillera.

The Western and the Eastern Cordillera reach much higher elevation as compared to the Central Highlands. In some of the ranges within the cordilleras, the summits reach to more than 5,000 and 6,000 $\mathrm{m}$ a.s.l. well above the average elevation of the Central Highlands. One might thus suspect that the two cordilleras owe their high elevations to variations in erodibility of the associated bedrock. Kühni and Pfiffner (2001) could show a correlation between lithology and topography for the Swiss Alps. There, higher mean elevations correspond to steep mean slopes which in turn correspond to bedrock with low erodibility (typically gneisses), and areas with high peaks correlate with bedrock with very low erodibility (typically granites). In the case of the Peruvian Andes, similar bedrock types (e.g., carbonates and sandstones) are spread throughout the Central Highland and at the same time form high summits within the Western Cordillera. Moreover, granitic rocks such as encountered in the Coast Batholith in the Western Cordillera and areas within the Eastern Cordillera do not correlate with high peaks. Even in the case of the Cordillera Blanca, many of the highest peaks are formed of sediments, the Cordillera Blanca batholith not being fully exposed at the surface. The high elevation of the Western and Eastern Cordillera must thus be explained by processes other than differences in erodibility. As will be discussed in the next paragraph, we think that the two cordilleras were uplifted by Quechua Phase faulting since about Mid-Miocene times.

Any young orogenic activity should leave an imprint on the morphology of the mountain chain. Diagnostic features to unravel tectonic forcing of morphology include the shape of river channels. Our analysis of river channels in the western escarpment of the Peruvian Andes yields that channel gradients are steep in the middle reaches of the rivers. The lack of any correlation between channel slope and bedrock lithology suggests that incision is controlled by external parameters, namely run off (climate) and/or tectonic activity. The extreme V-shape of the valleys and the absence of ongoing aggradation in the middle reaches of the rivers point to active incision. Here it has to be mentioned though that older gravel deposits are found on the flanks of some of the valleys. They include terraces and fans, which in turn were incised by the rivers. The most prominent terraces are found in the lower reaches of Rio Santa in northern Peru. Steffen et al. (2009a, b) dated terraces and fans in the lower reaches of Rio Pisco in central Peru and Rio Colca-Majes-Camaná in southern Peru. The age of these deposits is Pleistocene (younger than $60 \mathrm{kyr}$ for Rio Pisco, younger than $110 \mathrm{kyr}$ for Rio Colca-Majes-Camaná). Steffen et al. (2009a, b) relate the succession of terraces and their subsequent incision to climatic variations on the Altiplano and autocyclic feedbacks. The young age of the terraces underlines the rapid incision occurring along these valleys. Abbühl et al. (in press) determined high denudation rates of 10-250 $\mathrm{mm} \mathrm{ky}{ }^{-1}$ based on ${ }^{10} \mathrm{Be}$ data; these high incision rates correlate positively to precipitation rates and interpreted to be climate driven. Thouret et al. (2007) suspect that for Rio Colca-Majes-Camaná downcutting to the present valley floor was more or less completed between 9 and $3.8 \mathrm{Ma}$, but was followed by a refill owing to pyroclastic flows until $1.36 \mathrm{Ma}$ and finally a re-incision. All in all, the western escarpment has had a young, Pleistocene history of incision and backfilling controlled by climatic influences, whereas the older history of valley formation with the steep gradients and river gradient indices formed in response to tectonic forcing.

The eastern escarpment is also characterized by steep river channel gradients. However, on this eastern escarpment, a spatial correlation between gradient changes and thrust faults can be observed. Steep gradients are located upstream of east-vergent thrust faults. Some of these thrust faults are Neogene in age (Quechua Phase) and put older rocks onto Miocene and Pliocene sediments. In this case young (and maybe still active), thrust faults and associated rock uplift in their hanging wall are interpreted to be directly responsible for the steep gradients. The high local relief and extreme $\mathrm{V}$-shape of the valleys in segments where the rivers flow across the orogen suggest active river incision. In the lower reaches of these rivers, i.e., within the Subandean thrust belt, rivers flowing parallel to the orogen follow thrust faults in some instances. Examples include Rio Ene, Tambo and Ucayali. The position of these river segments just east of major thrust faults suggests that uplift of the hanging wall of the thrust faults created a ridge and displaced the river courses consistently outward into the foreland.

Our interpretation of young tectonic activity shaping river channels and river courses as gained from individual rivers is sustained by a regional analysis: Mapping stream gradient indices obtained from a multitude of rivers and their tributaries clearly reveals a belt of high values $(2,000-3,000$ and more) that follow the eastern and western escarpments. Along the western escarpment, this belt crosses lithologic units such as the Coast Batholith at low angles and again no correlation is discernible between the this belt and the outcrop pattern of the bed rock lithology. The high values 
themselves indicate pronounced tectonic activity. Similarly, the belt of high index values follows the major thrust faults along the eastern escarpment, a fact that also points to ongoing tectonic activity. This, together with the presence of high local relief, along both escarpments suggests that the Central Highland is a landform that was passively uplifted in the hanging wall of east-vergent thrust faults. As already pointed out, the age of these Quechua Phase thrust faults (Miocene) corresponds to the uplift age derived from paleobotanical considerations $(2,300-3,400 \mathrm{~m}$ of uplift since the Late Miocene after Gregory-Wodzicki 2000). Schildgen et al. (2007) determined the onset of this uplift at ca. $9 \mathrm{Ma}$ based on (U-Th)/He data, while Thouret et al. (2007) suggest that the onset of this uplift was earlier (at $13 \mathrm{Ma}$ ) and that incision of the western escarpment started at $9 \mathrm{Ma}$.

Our study demonstrates that Quechua Phase faulting was responsible for the uplift of the Western Cordillera in case of the Cordillera Blanca since Pliocene times (5-3 Ma after Petford and Atherton 1992; still ongoing) and around Abra la Viuda in the central area after Early Miocene times. But also in the central and southern parts of the Western Cordillera, faults uplifting Mesozoic sediments next to Cenozoic volcanics underline enhanced uplift of the Western Cordillera relative to the Central Highland.

Vertical faults also mark the boundary between the Eastern Cordillera and the Central Highland. However, the age of the activity of these faults has not been determined yet. In case of the Huaytapallana fault located NE of Huancayo, Suárez et al. (1990) determined ongoing reverse faulting with a left-lateral strike slip component based on focal mechanisms of earthquakes. Although recent earthquakes produced fault scarps indicating uplift of the Eastern Cordillera relative to the Central Highland, earlier ductile deformation features in the gneisses and marbles adjacent to the fault clearly indicate major strike slip motion. Thus, it seems that the Eastern Cordillera, too, owes its high elevation and high peaks to focused rock and surface uplift as consequence of tectonic forcing.

In summary, thrust-controlled morphology is present throughout the Peruvian Andes and some of the surface uplift is of young age and presently still ongoing.

Acknowledgments We acknowledge funding by the Swiss National Science Foundation, project \# 200020-122143 and the Canton of Bern. Our thanks go to Javier Jacay from the Universidad Nacional de San Marcos de Lima for his invaluable help in the field and at the University in Lima. Giovanni Aguero is thanked for his skillful driving on difficult and dangerous roads.

\section{References}

Abbühl LM, Norton KP, Jansen JD, Schlunegger F, Adahan A, Possner $\mathrm{G}$ (in press) Erosion rates and mechanisms of knickzone retreat inferred from ${ }^{10} \mathrm{Be}$ measured across strong climate gradients on the northern and central Andes Western Escarpment. Earth Surf Process Landf

Atherton M, Webb S (1989) Volcanic facies, structure and geochemistry of the marginal basin rocks of Central Peru. J S Am Earth Sci 2(3):241-261

Barazangi M, Isacks BL (1976) Spatial distribution of earthquakes and subduction of the Nazca Plate beneath South America. Geology 4:686-692

Berger A, Rosenberg C, Schmid SM (1996) Ascent, emplacement and exhumation of the Bergell pluton within the Southern Steep Belt of the Central Alps. Schweizerische Mineral Petrograph Mitt 76:357-382

Bishop P, Hoey TB, Jansen JD, Artza IL (2005) Knickpoint recession rates and catchment area: the case of uplifted rivers in $\mathrm{E}$ Scotland. Earth Surf Process Landf 30:767-778

Burbank DW, Anderson RS (2001) Tectonic geomorphology. Blackwell, Oxford

Burnett AW, Schumm SA (1983) Active tectonics and river response in Louisiana and Mississippi. Science 222:455-474

Cobbing EJ (1985) The tectonic setting of the Peruvian Andes. In: Pitcher MP, Atherton WS, Cobbing EJ, Beckinsale RB (eds) Magmatism at a plate edge: The Peruvian Andes. Blackie, Glasgow, pp 3-12

Goldrick G, Bishop P (1995) Differentiating the roles of lithology and uplift in the steepening of bedrock river long profiles: an example from southeastern Australia. J Geol 103:27-221

Goldrick G, Bishop P (2007) Regional analysis of bedrock stream long profiles: Evaluation of Hack's SL form and formulation and assessment of an alternative (the DS form). Earth Surf Process Landf 32:649-671

Gonzalez L (2011) Structure and morphology of the Central Andes of Peru: evolution of a mountain belt. PhD thesis, University of Bern

Gonzalez L, Pfiffner OA (in prep) Structure of the Central Peruvian Andes. S Am J Earth Sci

Gregory-Wodzicki KM (2000) Uplift history of the Central and Northern Andes: a review. Geol Soc Am Bull 112(7):1092-1105

Hack JT (1973) Stream-profile analysis and stream-gradient index. J Res US Geol Survey 1:421-429

Jaillard E, Soler P (1996) Cretaceous to early Paleogene tectonic evolution of the northern Central Andes $\left(0-18^{\circ} \mathrm{S}\right)$ and its relation to geodynamics. Tectonophysics 259:47-53

Jaillard E, Hérail G, Monfret T, Díaz-Martínez E, Baby P, Lavenu A, Dumont JF (2000) Tectonic evolution of the Andes of Ecuador, Peru, Bolivia and northernmost Chile. In: Cordani UG, Milani EJ, Thomaz A, Campos DA (eds) Tectonic evolution of South America, 31st international geological congress, Rio de Janeiro, pp 481-559

Keller EA, Pinter N (1996) Active tectonics: earthquake, uplift, and landscape. Prentice Hall, Upper Saddle River, p 338

Keller EA, Rockwell TK (1984) Tectonic geomorphology, quaternary chronology and paleoseismicity. In: Costa JE, Fleisher PJ (eds) Development and applications of geomorphology. Springer, Berlin, pp 203-239

Kühni A, Pfiffner OA (2001) The relief of the Swiss Alps and adjacent areas and its relation to lithology and structure: topographic analysis from a 250-m DEM. Geomorphology 41:285-307

Leopold L, Maddok T (1953) The hydraulic geometry of stream channels and some physiographic implications. US Geol Surv 252:1-56

Lindo R, Dorbath C, Cisternas A, Dorbath L, Ocola L, Morales M (1992) Subduction geometry in central Peru from a microseismicity survey: first results. Tectonophysics 205:23-29

Mackin JH (1948) The concept of a graded river. Geol Soc Am Bull 59:463-512 
McKeown FA, Jones-Cecil M, Askew BL, McGrath MB (1988) Analysis of stream-profile data and inferred tectonic activity, Eastern Ozark Mountains Region. Geol Surv Bull 1807:1-39

McNulty B, Farber F (2002) Active detachment faulting above the Peruvian flat slab. Geology 30:567-570

McNulty BA, Farber DL, Wallace G, Lopez R (1998) Role of plate kinematics and plate-slip-vector partitioning in continental magmatic arcs: evidence from the Cordillera Blanca, Peru. Geology 26:827-830

Mégard F (1978). Etude géologique des Andes du Pérou central: Contribution à l'étude géologique des Andes $n^{\circ} 1$. ORSTOM Mém 86, Paris, p 310

Mégard F (1984) The Andean orogenic period and its major structures in central and northern Peru. J Geol Soc Lond 1:893-900

Nott J, Young R, McDougall I (1996) Wearing down, wearing back, and gorge extension in the long-term denudation of a highland mass: quantitative evidence from the Shoalhaven catchment, southeast Australia. J Geol 104:224-232

Pardo-Casas F, Molnar P (1987) Relative motion of the Nazca (Farallon) and South American plates since Late Cretaceous time. Tectonics 6:233-248

Petford N, Atherton MP (1992) Granitoid emplacement and deformation along a major crustal lineament: the Cordillera Blanca, Peru. Tectonophysics 205:17-185

Ramírez-Herrera MT (1998) Geomorphic assessment of active tectonics in the Acambay Graben, Mexican Volcanic Belt. Earth Surf Proces Landf 23:317-332

Reed JC (1981) Disequilibrium profile of the Potomac River near Washington, DC - a result of lowered base level or Quaternary tectonics along the Fall Line. Geology 9:445-450

Rousse S, Gilder S, Farber F, McNulty B, Patriat P, Torres V, Sempere T (2003) Paleomagnetic tracking of mountain building in the Peruvian Andes since $10 \mathrm{Ma}$. Tectonics 22:1048

Schildgen TF, Hodges KV, Whipple KX, Reiers PW, Pringle MS (2007) Uplift of western margin of the Andean plateau revealed from canyon incision history, southern Peru. Geology 35:523-526. doi:10.1130/G23532A.1

Seeber L, Gornitz V (1983) River profiles along the Himalayan Arc as indicators of active tectonics. Tectonophysics 92:335-367

Seidl MA, Weissel JK, Pratson LF (1996) The kinematics and pattern of escarpment retreat across the rifted continental margin of SE Australia. Basin Res 12:301-316
Silver PG, Russo RM, Lithgow-Bertelloni C (1998) Coupling of South American and African Plate motions and plate deformation. Science 279:60-63. doi:10.1125/Sci.279.5347.60

Soler P, Bonhomme MG (1990) Relation of magmatic activity to plate dynamics in central Peru from Late Cretaceous to present. Special Pap J Geol Soc Am 241:173-192

Steffen D, Schlunegger F, Preusser F (2009a) Drainage basin response to climate change in the Pisco valley, Peru. Geology 37:491-494. doi:10.1130/G25475A

Steffen D, Schlunegger F, Preusser F (2009b) Late Pleistocene fans and terraces in the Majes valley, southern Peru, and their relation to climatic variations. Int $\mathrm{J}$ Earth Sci. doi:10.1007/s00531009-0389-2w

Steinberger B, Torsvik TH (2008) Absolute plate motions and true polar wander in the absence of hotspot tracks. Nature 452:620-630. doi:10.1038/natrueo6824

Steinman M (1929) Geologie von Peru. Karl Winter, Heidelberg

Suárez G, Gagnepai J, Cisternas A, Hatzfled D, Molnar P, Ocola L, Roecker SW, Viode JP (1990) Tectonic deformation of the Andes and the configuration of the subducted slab in central Peru; results from a microseismic experiment. Geophys J Int 103:1-12

Summerfield MA (1991) Global geomorphology. An introduction to the study of landforms. Longman Scientific Technical, Essex

Thouret JC, Wörner G, Gunnell Y, Singer B, Zhan X, Souriot T (2007) Geochronologic and stratigraphic constrains on canyon incision and Miocen uplift of the Central Andes in Peru. Earth Planet Sci Lett 263:151-166

Weissel JK, Seidl MA (1998) Inland propagation of erosional escarpments and river profile evolution across the southeast Australian passive continental margin. In: Tinkler KJ, Wohl EE (eds) Rivers over Rock: fluvial processes in Bedrock Channels, Geophysl Monograph 107 AGU, Washington DC, pp 189-206

Whipley KX (2004) Bedrock Rivers and the geomorphology of active orogens. Annu Rev Earth Planet Sci 32:151-185. doi:10.1146/ annuere.earth.32.101802.120356

Wilson J (1963) Cretaceous stratigraphy of Central Andes of Peru. Bull Am Assoc Pet Geol 47:1-34 